\title{
(c) (i) (S) \\ A formação contínua de professoras/es universitárias/os: afecções, afetos, emoções e sentimentos das perejivaniia docentes
}

\author{
Grasiela Maria de Sousa Coelho \\ Universidade Federal do Piauí - UFPI, Brasil \\ Andréa Maturano Longarezi \\ Universidade Federal de Uberlândia - UFU, Brasil \\ Apoio e financiamento: CAPES
}

\section{RESUMO}

Este artigo resulta de pesquisa em âmbito de doutorado, tendo por problema como e o que movimenta o processo formativo que prospecta a liberdade-felicidade do docente. Estabeleceuse como objetivo geral investigar, na Atividade Pedagógica, a prospecção liberdade-felicidade mediante o movimento coletivo do processo de formação e aprendizagem docente. Assumiu-se como método o Materialismo Histórico Dialético, fundamentando-se na Teoria HistóricoCultural da Atividade e na Didática Desenvolvimental, tendo como metodologia a Pesquisa Coletiva. Utilizou-se como instrumental a produção coletiva de textos em encontros formativos. O método de análise desenhou-se por meio dos isolados, episódios e cenas decorrentes da produção coletiva dos dados, tendo por categoria analítica a unidade. Apresentam-se, neste artigo, as afecções, afetos, emoções e sentimentos delineadores das perejivaniia no movimento da Atividade Pedagógica. Como resultado, concluiu-se que o sentido de pertencimento é vital para a Atividade Pedagógica, tem íntima conexão com a unidade motivo-objeto e com o aprendizado ético-afetivo.

PALAVRAS-CHAVE: Formação contínua. Docência universitária. Perejivaniia.

\section{THE CONTINUOUS FORMATION OF COLLEGE PROFESSORS AND PROFESSORS: AILMENTS, AFFECTIONS, EMOTIONS AND FEELINGS OF THE PROFESSORS' PEREJIVANIIA}

\begin{abstract}
This article results from research in doctoral range which aimed to investigate, having as a problema how and what moves the training process that prospects the freedom-happiness of the teacher. It was established as a general objective to investigate, in the Pedagogical Activity, the prospecto of freedom-happiness through the collective movement of the teacher training and learning process. The Dialectical Historical Materialism was adopted as a method, based on the Historical Cultural Theory of Activity and on Developmental Didactics, using Collective Research as a methodology. The collective production of texts in formative meetings was used as an instrument. The method of análisis was designed through the isolates, episodes and scenes
\end{abstract}


resulting from the collective production of data, having the unit as the analytical category. This article presents the "Ailments, affections, emotions and feelings delineators of the perejivaniia in the movement of the Pedagogical Activity". As a result, it was concluded that the sense of belonging is vital for the Pedagogical Activity, it has an intimate connection with the unit reason-object and with the ethic-affective learning.

KEY WORDS: Continuous formation. College Teaching. Perejivaniia.

\section{LA FORMACIÓN CONTINUA DE PROFESORAS/ES UNIVERSITARIAS/OS: AFECCIONES, AFECTOS, EMOCIONES Y SENTIMIENTOS DE LAS PERESHIVANIE DOCENTES.}

\section{RESUMEN}

Este artículo es el resultado de una investigación en el ámbito de doctorado, teniendo como problema cómo y qué mueve el proceso de formación que prospecta la libertad-felicidad del docente. Se estableció el objetivo general investigar, en la Actividad Pedagógica, la perspectiva de la libertad-felicidad mediante del movimiento colectivo del proceso de formación y aprendizaje del profesorado. Se adoptó como método el Materialismo Histórico Dialéctico, basado en la Teoría Histórica Cultural de la Actividad y en la Didáctica del Desarrollo, utilizando como metodología la Investigación Colectiva. Se utilizó como instrumental la producción colectiva de textos en encuentros formativos. El método de análisis se diseño a través de los aislados, episodios y escenas resultantes de la producción colectiva de datos, teniendo la unidad como categoría analítica. Aparece-se, neste artigo, como "Afecciones, afectos, emociones y sentimientos delineadores de las pereshivanie en el movimiento Actividad Pedagógica". Como resultado, se concluyó que el sentido de pertenencia es vital para la Actividad Pedagógica, tiene una conexión íntima con la unidad motivo-objeto y con el aprendizaje ético-afectivo.

PALABRAS CLAVE: Formación continua. Docencia universitaria. Pereshivanie.

\section{INICIANDO A CONVERSA}

De início, cabe registrar que esta pesquisa se situa em um grupo de pesquisas desenvolvidas no âmbito do GEPEDI (Grupo de Estudos e Pesquisas em Didática e Desenvolvimento Profissional Docente), formado por pesquisadoras/es e estudantes de pósgraduação do Programa de Pós-Graduação em Educação (PPGED/FACED) da Universidade Federal de Uberlândia (UFU/MG), que discutem "Intervenção Pedagógica" à luz da Didática Desenvolvimental, quais sejam: Dias de Sousa (2016); Ferreira (2019); Franco (2015); Marra (2018); Jesus (2021); Souza (2016, 2019) e Ferola (2016, 2019).

A problemática desta pesquisa versa, no todo, sobre reconhecimento e valorização da docência no ensino superior, acerca da omissão das políticas públicas no que tange à formação 
contínua de professores, das dicotomias entre a identidade profissional do professor e do pesquisador, das concepções de universidade, de ensino e de aprendizagem que o docente da educação superior possui, do desamparo dos professores na ausência dos conhecimentos pedagógicos, da legitimidade de um saber científico que desconsidera a dimensão pedagógica. Este artigo resulta de pesquisa em âmbito de doutorado, tendo como problema como e o que movimenta o processo formativo que prospecta a liberdade-felicidade do docente do Campus Amílcar Ferreira Sobral, da Universidade Federal do Piauí, situado na cidade de Floriano.

Estabeleceu-se como objetivo geral investigar, na Atividade Pedagógica, a prospecção liberdade-felicidade mediante o movimento coletivo do processo de formação e aprendizagem docente. Como objetivos específicos, tem-se: identificar as necessidades formativas dos professores partícipes da pesquisa; apreender as unidades dialéticas que movimentam o processo de formação na Atividade Pedagógica; compreender o significado social e o sentido pessoal da formação contínua para os professores do CAFS; sintetizar, no coletivo, os fundamentos da formação contínua que dimensionem o projeto institucional de formação contínua dos professores do CAFS.

Assumiu-se como método o Materialismo Histórico Dialético, fundamentando-se na Teoria Histórico-Cultural da Atividade e na Didática Desenvolvimental, tendo como metodologia a Pesquisa Coletiva, com base em Lênin (2011); Vigotski (1999, 2004, 2018); Davydov (1988); Longarezi (2013, 2018); Caraça (1951); Alvarado-Prada (2006,2008, 2010).

Utilizou-se como instrumental a produção coletiva de textos, movimento ocorrido para a sua efetivação por meio da organização dos encontros formativos, pela dinâmica de produção dos textos norteadores da proposta para a formação contínua. O método de análise, calcado na contradição, no movimento e na unidade, desenhou-se por meio dos isolados, episódios e cenas decorrentes da produção coletiva dos dados, tendo por categoria analítica a unidade. Como estratégia para execução da metodologia, após as discussões no grupo, foi acordado que seria elaborado um texto pelos partícipes da pesquisa sobre a concepção de formação contínua, elencando três características, no mínimo, sobre tal formação. Após a elaboração, os textos foram apreciados por cada um dos partícipes, de modo que puderam expor o seu entendimento, argumentando e/ou contrargumentando acerca das ideias apresentadas em cada texto, de modo que, a partir da discussão, chegou-se a um consenso sobre que características seriam indispensáveis à formação contínua.

Como resultado apresentam-se, neste artigo, as afecções, afetos, emoções e sentimentos delineadores das perejivaniia no movimento da Atividade Pedagógica, tendo em vista que, no todo, esta pesquisa tratou da relação entre o trabalho docente, atividade pedagógica, formação 
contínua de professores universitários e a produção da liberdade-felicidade. Como parte do resultado, concluiu-se que o sentido de pertencimento é vital para a Atividade Pedagógica e tem íntima conexão com a unidade motivo-objeto e com o aprendizado ético-afetivo.

Isso posto, assevera-se que a relação dialética alimenta o trabalho docente, enquanto permanente e incessante busca pelo conhecimento como necessidade cotidiana do seu métier. E, nesse entrelaçamento conflituoso, entre buscas, inércias, avanços, retrocessos, vai se constituindo o ser docente que encontra no anthropos e na sua relação com o conhecimento e com a aprendizagem, obstinado modo de expansão da consciência, compreendendo-a a partir da relação com a cultura, com vistas à humanização. Portanto, podem ser criadas as condições do vir-a-ser e, consequente, desejo para perseverar na existência humana, por meio da cultura presente nos objetos e difundida por meio da linguagem. Desse modo, a humanidade vai se constituindo nas relações sujeito-conhecimento e sujeito-sujeito, por meio da aprendizagem que provoca o desenvolvimento cíclico, mas não linear, porque demarcado por crises e movido pela contradição na/da vida vivida. Cultura é o processo histórico manifestado como produto da vida humana, em movimento dialético por meio da transformação da natureza, conjuntamente com o desenvolvimento das funções psicológicas superiores e da atividade da conduta humana, considerando a filogênese e ontogênese enquanto processos essencialmente distintos. Neste processo, ocorrem crises que desencadeiam novas crises, provocando novas aprendizagens e novos desenvolvimentos.

A humanidade do professor dá-se pari passu à sua formação oportunizadas pelo trabalho docente e produzindo o seu modo de ser, de pensar, de sentir e de agir. Nessa constituição, estar e ser com os seus pares é condição sine qua non para o avanço da aprendizagem na e sobre a docência, tendo em vista que é na expansão da aprendizagem por meio do outro, com o outro, favorecendo a tecitura da rede de relações necessária à compreensão do conhecimento que a docência vai se constituindo. Em sendo a docência atividade que concebe em seu interior a finalidade de humanizar o ser, há que se considerar que lida com tarefa que, na aparência, pode parecer redundante, porém não o é em sua essência essa necessidade redundante, tendo em vista a estrutura e organização da sociedade dividida em classes e arrolada de modo fulcral no capitalismo, o que cria ambiente propício à reificação.

Isso posto, torna-se premente que a docência seja calcada nas condições objetivas da realidade, considerando os conhecimentos prévios dos professores e, particularmente, as condições de trabalho e formação, pois a aprendizagem constitui-se tanto em processo como em produto da profissão docente, exigindo tanto o domínio dos conhecimentos generalizados como daqueles específicos, como a capacidade de ter que lidar com fenômenos sociais de 
naturezas diversas e amplas, donde surge a inescapável tarefa de também educar, além de ensinar. Enquanto profissão, tendo a docência um vasto alcance, é inevitável a relação com a cultura instalada no meio social, relação essa que pode ser de confluência e/ou confronto. É exatamente nessas confluências e/ou confrontos que o ser professor vai se constituindo por meio do trabalho docente: frente ao conhecimento, a seus pares, aos discentes e na amálgama composta por esses elementos dessa teia de relações sociais, culturais, históricas, econômicas e políticas. Considerando o exposto, adiante registram-se os fundamentos que dimensionaram o aspecto teórico-metodológica desta pesquisa.

\section{PEREJIVANIIA ${ }^{1}$ DOCENTES E O COLETIVO PROFISSIONAL: O DESENHO TEÓRICO-METODOLÓGICO}

Cabe, portanto, explanarmos sobre o quadro político em que estamos imersos atualmente e a problemática desta pesquisa, sob embargo no que diz respeito ao desgaste das relações sociais de um modo geral e, consequentemente, à docência, já bastante desgastada quanto ao reconhecimento e valorização, sofre esse impacto. Dado o potencial formativo e humanizador ao qual se propõe esta pesquisa, convém contextualizar acerca da omissão das políticas públicas no que tange à formação contínua ${ }^{2}$ de professores, das dicotomias entre a identidade profissional do professor e do pesquisador, das concepções de universidade, de ensino e de aprendizagem que o docente da educação superior possui, do desamparo dos professores na ausência dos conhecimentos pedagógicos, da legitimidade de um saber científico que desconsidera a dimensão pedagógica, realizando cada professor o seu trabalho de acordo com o que acredita, produzindo saídas diversificadas, por vezes tomando por base a imitação,

\footnotetext{
${ }^{1}$ Conforme Vigotski (2018), as perejivaniia constituem a unidade indivisível da consciência, materializadas napela vida vivida e indelevelmente relacionadas às emoções e contradições, que desencadeiam as catarses provocadoras do desenvolvimento humano. De acordo com Vygotsky (2004a, p. 71), a "consciência é a vivência das vivências [...]", outrossim, "[...] a imaginação e a fantasia devem ser vistas como funções a serviço da nossa esfera emocional e, mesmo quando revelam semelhança externa com os processos de pensamento, a emoção está sempre na raiz desse pensamento." (VYGOTSKY, 1999, p. 56). Portanto, toda perejivanie ocorre em contextos reais que provocam emoções reais, em uma unidade dialética que expressa sentimentos, afetos e afecções: "[...] as emoções angustiantes e desagradáveis são submetidas a certa descarga, à sua destruição e transformação em contrários, [...] ou seja, à complexa transformação dos sentimentos." (Idem, ibidem, p. 270). Dessa maneira, a estrutura dramática das perejivaniia tem como baldrame a contradição, motor da atividade social humana, posto que à vida real "[...] entrelaça-se algum motivo irreal, que começamos a interpretar também como motivo real em termos absolutamente psicológicos, e a luta entre esses dois motivos incompatíveis é o que produz a contradição, que deve necessariamente ser resolvida na catarse [...].” (Idem, ibidem, p. 298).

${ }^{2}$ Nesta pesquisa, utilizar-se-á a expressão contínua ao invés de continuada por entender que, linguisticamente falando, continuada é algo que tem previsão de início, meio e fim, um projeto específico, uma formação específica, com carga horária específica; já a contínua traz a característica de algo que não tem previsibilidade de terminar. É também uma formação posterior à inicial, assim como a continuada, só que não é um projeto específico de carga horária fechada. É uma formação que o tempo todo está sendo renovada ad infinitum, posto que as necessidades formativas não cessam e estão em contínuo surgimento e transformação.
} 
ensinando por tentativa e erro, o que incorre em amadorismo e dificulta o entendimento do que seja o ato educativo, diminuindo-o à mera condição de transmissão.

Salienta-se que, no CAFS/UFPI, funcionam o Ensino Básico, Técnico e Tecnológico (EBTT) e Nível Superior (ES), em prédios separados, porém no mesmo Campus. Portanto, concepções diversas de universidade e de ensino, marcadas inclusive pelo próprio caráter institucionalizado de cada nível de ensino. A partir da intrincada rede de relações sociais, culturais, históricas, econômicas e políticas, particularmente aquela que se estabelece entre trabalho e formação, questionou-se sobre o que os professores entendem acerca da formação contínua, o que esperam dela, quais são as suas necessidades formativas, se a formação contínua impacta na vida pessoal e profissional do professor, delimitando como problema desta pesquisa: como e o que movimenta o processo formativo que prospecta a liberdade-felicidade do docente do CAFS?

No atual governo (2019-2022), há ênfase no aspecto ideológico, na vigilância de professores e em uma pedagogia meramente transmissiva tem como objetivo escamotear os reais problemas da educação, dentre eles, a formação docente. A fim de causar distração da sua real intencionalidade que é agravar o desmonte da educação superior, acelerar o processo de privatização da universidade pública brasileira, tal governo circunscreve a crise da educação vinculando a moralidade exclusivamente à religião e à obediência, enquanto que o desenvolvimento moral, na sua vastidão, está intrinsicamente relacionado à expansão da intelectualidade humana, do aprendizado ético, afetivo e social. Para tanto, ligar o conhecimento a vários contextos é condição sine qua non para se instalar a dúvida, fomentando a capacidade de interpretação da complexa realidade social, que é histórica, contraditória e tem como base a materialidade e diversidade dos fenômenos sociais.

Destarte, no capitalismo, "o trabalho assume centralidade, mas não na sua dimensão ontocriativa e sim como uma mercadoria especial, força de trabalho a ser negociada no mercado" (FRIGOTTO, 2009, p. 130), que gere uma mercadoria ou serviço. Ocorre que, no campo educacional, o resultado desse trabalho é em longo prazo, é um processo social, cultural e histórico que, se compreendido pela lógica dialética, ocorre de modo a contestar os mecanismos de alienação política, a fim de produzir o pensamento contra hegemônico que combata a consciência de subordinação, produzindo o trabalho que prime pelo valor de uso, bem como expandindo o tempo de liberdade. Entendido dessa maneira, o trabalho forja possibilidades de apropriação, criação e recriação pela via do conhecimento, tecnologia e ciência transformando a natureza com a finalidade de impulsionar a existência humana.

Para além das políticas públicas, precípuas para o avanço da formação de professores, 
considerando que a formação não é responsabilidade única e principal do professor, de acordo com Alvarado-Prada e Longarezi (2008, p. 113) “[...] os professores precisam aprender em e no trabalho coletivo a criar situações de aprendizagem coletiva, tanto para eles como para os alunos e a sociedade em geral.", tendo em vista ser esse o lugar social primoroso para a construção dos coletivos, alternativa possível de contra-argumentação ao sistema que paramenta a individualidade em detrimento de uma sociedade mais igualitária. Caso contrário,

[...] a partir das mais altas estruturas do poder (neste caso do conhecimento, da academia) em vez de aprendizagens para a transformação se continuará reforçando uma educação e uma aprendizagem confundida com transmissão de conhecimentos, possivelmente importante desde uma lógica racionalista, porém descontextualizada da realidade da aprendizagem docente e conservadora ou dificultadora da situações que, em seus próprios discursos, anunciam necessidade de mudanças e transformações (ALVARADOPRADA; LONGAREZI, 2009, p. 118).

$\mathrm{Na}$ atual conjuntura política nacional e global, particularmente, convém ainda mais o ensino e a educação para a insurgência, a subversão, a ruptura dos silêncios, a quebra de paradigmas, de estruturas cristalizadas pelo poder como mecanismo de resistência. A travessia exige. O tempo da travessia certamente extrapolará a cronologia porque será cronometrado pelo impacto das afecções, afetos, sentimentos, emoções e da afetividade $^{3}$ em corpos-mentes. Comporá ética, afetiva, histórica e humanamente o ser-tornar-se-sentir-se professor: é preciso equilíbrio em meio ao caos, é preciso coragem. Em tempos de desmonte da pesquisa, da educação e do próprio sentido ético da vida é preciso reação: talvez por não ter sido feito adequadamente a travessia no momento histórico em que isso coube. Quando coube o rompimento, adiando o inadiável, optou-se pela coalizão no contexto político brasileiro, como se fosse possível coalizão com o antagônico, que difere brutalmente do contraditório, mola propulsora da atividade humana social. Outrossim, ao se considerar a atividade do trabalho docente e da formação de

\footnotetext{
${ }^{3}$ Acerca da compreensão spinozana sobre a constituição da afetividade, Sawaia (2000, p. 13 a 15), aponta que: “[...] afetos são afecções instantâneas de uma imagem de coisas em mim nas relações que estabeleço com outros corpos. São modificações, pois envolvem sempre um aumento ou diminuição da capacidade dos corpos para a ação e obriga o pensamento a mover-se em uma direção determinada, neste sentido há afecções boas e más. [...] afecção é instantânea, é o efeito imediato de uma imagem de coisa sobre mim, o momento presente da percepção e envolve um passo ou uma transição vivida do estado precedente ao atual. [...] o afeto é algo que a afecção envolve, é a transição vivida do estado precedente ao atual e do atual ao seguinte. $\mathrm{O}$ afeto aparece sob a forma de duração que varia em tempo e intensidade. [...] A emoção é o afeto que irrompe na relação imediata e é momentânea, breve, centrada em objetos ou imagens que interrompem o fluxo normal da conduta de alguém, provocando modificações corpóreas e comportamentais, facilmente constatáveis. [...] Sentimento é a emoção sem prazo, com longa duração, que não se refere a coisas (objetos ou ideias) específicas. É o tom emocional que caracteriza a forma como me coloco no mundo. Por exemplo, a emoção de medo é o que sinto frente a um perigo eminente. O sentimento de medo é o que caracteriza minha identidade: sou um homem medroso. [...] Afetividade é o nome atribuído à capacidade humana de elevar seus instintos à altura da consciência, por meio dos significados, de mediar a afecção pelos signos sociais, aumentando ou diminuindo nossa potência de ação".
} 
professores, a tese a ser confirmada ou não nessa pesquisa foi estabelecida nos seguintes termos: a constituição do ser-tornar-se-sentir-se docente a partir das unidades que eclodem na Atividade Pedagógica geram, pelo devir histórico e contradição, a constituição da personalidade humana que evoca, por meio do coletivo, as possibilidades emancipatórias de exercício da politicidade e da ética, oportunizando a distinção entre essência e aparência.

Por meio de abstrações e mediações distintas acerca do objeto, do método, da metodologia e do contexto, principiou-se o novo ponto de partida que, todavia, mantém-se como representação. À vista disso, entre o objeto e o concreto, o particular e a totalidade abstrata, existe a catarse longa, extenuante e potente do processo, que vai se revelando de modo não linear pela investigação, no movimento de ascensão do abstrato ao concreto. $\mathrm{O}$ método de pesquisa foi calcado na contradição, no movimento e na unidade, por meio dos isolados, episódios e cenas decorrentes da produção coletiva dos dados, a fim de se alcançar as relações internas do lógico-histórico do fenômeno em questão: a empiria - na relação com as abstrações produzidas pelo grupo de partícipes - foi decomposta para que fosse possível a sua posterior análise e síntese, procedendo com o registro da compreensão do fenômeno alcançada, tendo por categoria analítica a unidade.

Por isolado entende-se os recortes, os destaques da totalidade, quer seja, "um conjunto de seres e factos, abstraído de todos os outros que com eles estão relacionados [...] de modo a compreender nele todos os fatores dominantes [...] todos aqueles cuja acção de interdependência influi sensivelmente no fenômeno a estudar." (CARAÇA, 1951, p. 112). Tomaram-se por isolados os conteúdos dos encontros realizados com os professores partícipes da pesquisa e as assembleias de curso para a discussão da proposição que ora é defendida, instrumentalizada pela materialização advinda das produções textuais, bem como dos áudios transcritos contendo os diálogos travados nas reuniões em que se efetivaram ações formadoras, instrumentalização esta que se constituíram em base para designação dos episódios de formação.

Episódios, na voz de Moura (2000, p. 59), "são ações reveladoras do processo de formação dos sujeitos participantes de um isolado [...] que revelam mudança (qualidade nova) [...]" naquilo que os sujeitos de determinado grupo se propõem a realizar e que é definido no coletivo. Outrossim,

Os episódios serão reveladores sobre a natureza e qualidade das ações. Quanto à natureza, podemos destacar: se se trata de conceito, de modos de ação, de valores, de conhecimento estratégico (organização do trabalho coletivo e das relações de trabalho, criação de atividades desencadeadoras de aprendizagem), ou se é apenas conhecimento prático. Quanto à qualidade, os episódios poderão revelar se se trata de ações coordenadas pelos motivos individuais ou coletivos, se visam à concretização da atividade ou feitos sem 
vínculo com os motivos destas ações, se articulam análise e síntese na avaliação das ações. (MOURA, 2000, p. 60).

Dada essa definição, Moura (2000) afirma que é necessário delimitar com precisão o começo, o fim dos episódios, suas composições e as interdependências entre as ações dos isolados selecionados, assinalando que esse processo é resultante de ações não lineares. Assim, por meio das cenas que constituem unidade nos episódios, "O pesquisador, tal como o produtor de cinema, é que faz a leitura dessas várias ações, que parecem isoladas, à procura das interdependências reveladoras do modo de formar-se". (MOURA, 2000, p. 64). Desse modo, foi necessário para a efetivação deste trabalho a organização da atividade formativa no espaço do CAFS, de maneira que se pudesse confrontar as práticas, as compreensões acerca das concepções de formação contínua, a fim de que houvesse avanço para o consenso sobre tal temática. No limite do planejado, dadas as condições da sua efetivação, é que houve aproximação com a não linearidade, a inspiração, a percepção e a compreensão do emaranhado de relações que engendraram o fenômeno em questão, a partir do trabalho coletivo e das necessidades do grupo, evidenciando que:

O conceito de isolado, se agregado ao de atividade, permite-nos relativizar as ações e definir um modo de analisá-la, tendo em vista o isolado tomado como referência. É necessário que tenhamos a clareza de que as ações práticas podem, de algum modo, ser apenas circunstanciais. Isto porque as atividades podem ser tomadas em isolados. Estas atividades podem ter a dimensão de ações em atividades mais complexas se vistas em novos isolados. [...] O sujeito que está à espreita do animal executa uma determinada ação que é parte de uma atividade, a caçada, mas no isolado que caracteriza a espreita ele realiza uma atividade: tem um motivo, executa uma ação e tem as condições objetivas [...]. (MOURA, 2000, p. 66).

Assim, definir o isolado desse fenômeno histórico - a formação contínua dos professores do CAFS - foi o início do processo de análise, após o conflito inicial do contato com os dados, passando pelos corpus bruto, empírico até alcançar o analítico, em contínuas retomadas: no início o caos para, em seguida, chegar ao concreto pensado até alcançar à condição de exposição, estabelecendo a conexão com o método de pesquisa. Os episódios, os isolados e as cenas têm unidade, com distintas identidades entre si, expressando a dialeticidade inerente ao Materialismo Histórico, o que possibilitou evidenciar as múltiplas determinações nas suas relações essenciais, distinguindo a essência da aparência no fenômeno histórico em movimento. Com base nessa compreensão e tendo em mente a definição dos objetivos desta pesquisa, analisaram-se os isolados e episódios selecionados, nas suas interdependências, considerando a complexidade na qual a universidade pública brasileira está envolta 
universalmente, captando as particularidades do fenômeno e considerando as singularidades dele no CAFS, a fim de legitimar o que ficou entendido como proposta de formação contínua, norteada pelas necessidades e motivos do coletivo ${ }^{4}$.

Tendo em vista os objetivos desta pesquisa, a pesquisa coletiva possibilitou a criação de contextos em que os partícipes elaboraram textos escritos individuais e coletivos ${ }^{5}$, baseados em critérios e características produzidas no coletivo, intencionando, por meio do confronto, da avaliação e da sistematização, a contínua retomada do que tinha sido trabalhado em encontros anteriores, objetivando a descrição, a análise e a síntese, constituindo o processo em pesquisaformação que é fomentado por uma trama de relações singulares. A constituição do coletivo suscitou conhecimentos sobre cada um e sobre a totalidade, ou seja, evidenciando características das identidades individuais e coletivas, dos objetivos do coletivo e do movimento para alcançá-los. Evidenciaram-se também conhecimentos sobre as características da dinâmica de constituição do coletivo, a produção de seus objetivos e o movimento para alcançá-los, aflorando o caráter formativo da pesquisa coletiva que "permite aos seus participantes formarem-se e atuarem como pesquisadores de e na construção de sua própria realidade" (ALVARADO-PRADA, 2006, p. 110), criando o espaço e o tempo em que foram evocados os seus desejos, interesses, necessidades formativas e o compartilhamento dos desafios e dificuldades encontrados na docência na universidade.

Conforme Alvarado-Prada (2006), a concepção teórico-metodológica da pesquisa coletiva afasta-se dos modelos que, em nome da objetividade, entendem a não-alteração da realidade como neutralidade ou a fidedignidade à verdade. Desse modo, os dados não foram somente coletados pela pesquisadora, mas produzidos continuamente nas fases da pesquisa, por meio das interações do coletivo e dos seguintes procedimentos: o diálogo, a construção da própria metodologia e a construção do coletivo. $\mathrm{O}$ diálogo possibilitou que, no compartilhamento de conhecimentos, surgissem elementos tanto das relações interpessoais, como de cada pessoa com seus próprios conhecimentos. Confrontar-se, pois, com seus próprios conhecimentos, requer a existência do outro, a fim de expandir o amplo e real sentido desses conhecimentos. Uma vez ocorrido o confronto, os conhecimentos se transformaram em uma amálgama em que não havia mais o pertencimento dos conhecimentos a cada um, pois houve

\footnotetext{
${ }^{4} \mathrm{O}$ coletivo, no contexto desta pesquisa, foi composto inicialmente pelo grupo de partícipes que aderiu de modo volitivo à atividade formativa proposta e, posteriormente, expandiu-se ao apresentar a discussão sobre formação contínua nas assembleias de professores (Cursos de Licenciatura em Pedagogia e Biologia; Curso de Bacharelado em Administração).

${ }^{5}$ A partir da produção individual dos textos, cada partícipe teve acesso aos textos dos demais e, utilizando o revisor do word, foi fazendo os registros que avaliava como necessário nos textos dos demais. Após os registros, os partícipes se reuniram para discutir sobre tais registros, de modo que se chegasse a um consenso. Esse movimento possibilitou a transição dos textos individuais em textos coletivos.
} 
compartilhamento que gerou novos conhecimentos. A construção da própria metodologia de pesquisa foi desenvolvida no coletivo, considerando a formação para e na construção de conhecimentos, em um caleidoscópio dos fundamentos teórico-metodológicos de cada participante, aprimorando as capacidades de negociar, lidar com as diferenças, fazer consensos e elaborar acordos.

A orientação epistemológica da pesquisa coletiva, na voz de Alvarado-Prada (2006), é focada na relação sujeitos-sujeitos, ou seja, abrange todos os envolvidos, inclusive quem propõe/coordena a pesquisa, tendo em vista que os dados, os objetos e conhecimentos são produzidos coletivamente, não havendo a distinção pesquisadores/pesquisados. Esse movimento dialético, posto que se move a partir das argumentações e contra argumentações, visa o consenso, gera o "rigor da pesquisa em função da aproximação das explicações [...] sobre a situação objeto [...] derivadas de elementos ideológicos, políticos, sociais e culturais específicos do coletivo" (ALVARADO-PRADA, 2006, p. 111) que, não obstante situem-se no campo do conhecimento científico, são produções resultantes das relações subjetivas. A devolutiva dos dados produzidos pelo coletivo ocorreu pela via das ações comunicativas, objetivando uma contínua reconstrução por meio de atualizações, correções e alterações. Há que se considerar a dimensão política desse processo, uma vez que os partícipes estavam envoltos nessa atmosfera permanentemente, pois se formaram e foram formados politicamente nesse emaranhado de relações, quer seja "concordando ou fazendo resistência a elas, construindo as políticas locais e institucionais [...], formando politicamente os alunos" (ALVARADOPRADA; OLIVEIRA, 2010, p. 113), o que oportunizou a dialogicidade, considerando também as dimensões pedagógica, técnica e as concepções teórico-metodológicas.

No entendimento de Alvarado-Prada e Oliveira (2010, p. 119), “[...] as atuais políticas de formação continuada [...] tendem para um aligeiramento e barateamento dessa formação. O que [...] provoca seu empobrecimento e desqualificação [...].” Os referidos autores criticam o destaque aos aspectos mais imediatistas, por exemplo, técnicas de transmissão de conhecimentos e metodologias de ensino, em detrimento "[...] das perspectivas ideológicas, históricas, culturais e sociais do trabalho dos professores, dificultando, ao invés de facilitar, a análise e compreensão das diferentes concepções que as permeiam [...]." (ALVARADOPRADA; OLIVEIRA, 2010, p. 120). Outro aspecto considerado são os elementos necessários à formação contínua, quais sejam: tempo, espaço e meios viabilizadores dessa formação, de modo que seja assegurada a continuidade com base no ser, no fazer e no pensar, exigindo investimento no coletivo. 
A pesquisa coletiva, no entendimento de Longarezi e Silva (2013), enfatiza a contribuição de cada sujeito na produção do conhecimento, a partir da experiência social de cada um, a partir dos conhecimentos científicos, mas também com base na realidade e na subjetividade de todos/as os componentes do grupo, bem como nas experiências profissionais, o que provoca o desenvolvimento autônomo e consciente. Esse movimento vai gerando a conscientização por meio da apropriação crítica do conhecimento, que conduz a aprendizagem ou transformação, viabilizando a construção de novos conhecimentos. Nesse sentido, AlvaradoPrada e Longarezi (2008, p. 114) entendem que "exigir dos professores aprendizagem [...] de conhecimentos desenvolvidos por outros e que são alheios à vida cotidiana profissional, mostra que quem faz tais exigências, não aprendeu como se aprende e como é que os docentes querem e o que estes precisam aprender."

Considerando o desenho teórico/metodológico apresentado, escolheu-se como instrumental para a realização da pesquisa o questionário semiaberto ${ }^{6}$, a produção de textos individuais e coletivos, bem como o estudo de textos com temáticas relativas à efetivação dos objetivos da pesquisa. O questionário foi enviado por e-mail para todos os professores efetivos do Campus Amílcar Ferreira Sobral, que, à época (2016), totalizava cento e cinco (105). A fim de se conhecer a realidade, aplicou-se, primeiramente, o questionário semiaberto para traçar o perfil profissional e acadêmico dos partícipes da pesquisa, como também para diagnosticar as especificidades relacionadas à questão-problema e aos objetivos da pesquisa. Dos trinta e seis (36) professores que se dispuseram a participar da pesquisa, quando consultados por e-mail, somente vinte e um (21) mantiveram o interesse para a efetiva constituição do grupo, justificando os demais a não continuidade no propósito por conta dos inúmeros compromissos assumidos com a UFPI, quer sejam relacionados à tríade ensino/pesquisa/extensão, quer seja com as suas próprias pós-graduações (mestrados e doutorados). Dos vinte e um (21) docentes interessados em participar da pesquisa, somente foi possível a participação de seis (06) em função de incompatibilidade de horários e dias de permanência no Campus.

$\mathrm{Na}$ constituição do grupo, consideraram-se os seguintes critérios: um representante de cada curso (houve representação dos Cursos de Licenciatura em Pedagogia e Biologia; do curso de Bacharelado em Administração; do Ensino Médio - EBTT) e formações iniciais diversas entre si (duas formações iniciais em Licenciatura em Pedagogia; duas formações iniciais em Licenciatura em Biologia; uma formação inicial em Bacharelado em Administração; uma formação inicial em Licenciatura em História), bem como a disponibilidade destes para a

\footnotetext{
${ }^{6}$ Apenas questões objetivas não dariam conta da discursividade inerente ao conteúdo dos questionamentos, por este motivo optou-se pelo tipo semi-aberto.
} 
participação na atividade formativa. Esta foi a constituição do grupo nuclear que, posteriormente, expandiu-se em função de as discussões terem ocorridos também nas assembleias de cursos aos quais foi possível de se realizarem. Os partícipes foram designados por codinomes: o primeiro nome de cada um faz referência à prospecção liberdade-felicidade, enquanto devir; o segundo nome de cada um é alusivo aos sobrenomes da poetisa e dos poetas autores das epígrafes deste trabalho. Na fase de expansão do coletivo de partícipes, os presentes nas assembleias de professores dos cursos de Pedagogia e Biologia, que tiveram seus discursos citados na tese, foram nomeados com os sobrenomes dos poetas e poetisas em primeiro lugar, e, como sobrenome, vêm os temas referentes à prospecção liberdade-felicidade.

Que nos chegue a bravura, a calma, a intensidade, o compromisso, a reciprocidade social, a força do afeto e do intelecto materializados pelos coletivos, impactando na expansão da consciência crítica. Na voz de Spinoza $(1662$, p. 3) "[...] toda a felicidade ou infelicidade consiste somente numa coisa, a saber, na qualidade do objeto ao qual aderimos pelo amor", pois que mutatis mutandis “[...] é possível uma felicidade diferente, real [...] ligada não à realização pessoal, mas ao entusiasmo de trabalhar em função de um evento, de uma ruptura na ordem estabelecida, e assim poder dar corpo a uma novidade no mundo." (BADIOU, 2015, p. 1). Uma novidade que afaste o trabalho docente das tarefas destrutivas e mecânicas e que o aproxime das tarefas sociais e revolucionárias.

Com apoio nessa discussão, esta pesquisa tem como princípios norteadores: a contradição, o movimento e a unidade (grifos nossos). Entende-se que a contradição move a trama que tece a própria vida de maneira não linear, sendo a morte (de tudo e todos) inerente à existência, dada em um movimento de permanente confronto de pensamentos-atividadesemoções como o nuclear das forças mobilizadoras do desenvolvimento. A contradição efetivase como unidade e por unidades, é o motor que carreia a existência humano-cultural, gerando força que impulsiona a superação-desenvolvimento e revelando a essência enquanto compreensão da síntese da luta entre contrários, da negação da negação, da mudança do quantitativo para o qualitativo e vice-versa.

A unidade fundamenta a obutchénie ${ }^{7}$ dialética e desenvolvedora no contexto da vospitanie, contendo em si mesma a inclusão/exclusão, o consenso/dissenso, a necessidade/

\footnotetext{
7 Obutchénie, segundo Longarezi e Dias de Sousa (2018), é a unidade primária que contempla ensinoaprendizagem, a partir da perspectiva histórico-cultural da atividade, podendo oportunizar a unidade obutchéniedesenvolvedora, se criadas as condições adequadas que viabilizem o confronto com as vivências para que ocorram processos psíquicos internos aos sujeitos, a fim de que a aprendizagem, enquanto síntese dialética, efetive-se como desenvolvimento.
} 
motivo e, sob esta base, constitui-se o sujeito sociopessoal ${ }^{8}$ ao produzir a si mesmo e a humanidade de modo concomitante, por meio dos confrontos na insurgência do novo, no movimento do lógico e do histórico articulado pelos nexos conceituais. Na dialeticidade, a vida e os conceitos são essencialmente considerados em seus nexos, cadenciados em devir e perecimento, manifestando a totalidade do mundo no processo do desenvolvimento, mediatizado pela linguagem que, a partir do modo particular, provém a conexão entre o universal e o singular e às transformações progressivas e regressivas da matéria.

Assim, a liberdade-felicidade enquanto produção social humana, aqui fundamentada no Materialismo Histórico Dialético, na Teoria Histórico-Cultural, na Teoria da Atividade e na Didática Desenvolvimental, evoca o mergulho na cultura e convida ao pensamento politizado, é chama que exige a tomada de consciência, não se constituindo do solos ipse, tendo em vista que tudo ao nosso redor impacta na produção desse processo de natureza dialética. Em nada, a liberdade-felicidade, que é impulsionada pela tomada de consciência, assemelha-se às ilusões do contemporâneo contexto capitalista, com seus falsos truísmos aprisionadores da consciência humana, pois, dar-se conta da realidade compreende ampliar a consciência, reconhecendo nela uma origem social, pois, como afirma Vygotsky "pode haver graus de consciência [...]. A consciência das próprias sensações significa apenas que elas atuam como objeto (excitante) de outras sensações: a consciência é a sensação das sensações, exatamente da mesma forma que as simples sensações são a sensação dos objetos." (VYGOTSKY, 2004a, p. 14). Desse modo, as sensações constituem-se em umbral para a apropriação dos significados, porque carreiam à formação dos conceitos por meio dos nexos conceituais. As denominações dos objetos e a consciência sobre eles, quando ampliada, potencializam o desenvolvimento das funções psicológicas superiores em suas conexões, ao buscar as suas relações na totalidade, o que promove o desenvolvimento integral do humano, sobre o qual trata-se a seguir, de maneira situada no universo profissional do docente universitário.

Convém asseverar que priorizar a felicidade e a liberdade enquanto produções sociais que anteponham a condição humana, fazendo escolhas teóricas e pedagógicas que impulsionem a educação, significa, ao mesmo tempo, contemplar a ruptura, a imaginação e a criação, evocando o aprendizado ético-afetivo, entendendo ética como "[...] a capacidade do corpo e do pensamento em selecionar, nos encontros, o que permite ultrapassar as condições de existência na direção à liberdade e felicidade, como um aprendizado contínuo.” (SAWAIA, 2003, p. 59).

Esse é um tema caro aos estudos filosóficos e psicológicos que envolve a inscrição da

\footnotetext{
${ }^{8}$ É a "[...] dimensão da pessoalidade produzida pelo humano que também é o produtor do social [...] unidade sujeito-sociedade.” (LONGAREZI; DIAS DE SOUSA, 2018, p. 460, nota 9).
} 
afetividade na linguagem: na atividade humana não há separação entre as abstrações conceituais e a própria vida vivida, um constitui o outro e coloca em cena o sujeito encarnado, não um mero corpo biológico, mas um corpo-linguagem-mente-emoção. A linguagem que expressa e produz emoção sustenta-se nas interações que constituem os sentidos entre sujeitos localizados em um contexto específico, com uma gama de pontos de vista, desejos e intenções decorrentes das perejivaniia partilhadas ou não. De acordo com Leontiev (2004, p. 109 e 111), os sentidos expressos pelas:

[...] significações linguísticas que se criam na atividade coletiva de trabalho não refletem apenas as relações dos homens com a natureza, mas também as relações dos homens entre si. Mas as relações que têm os diferentes participantes do trabalho coletivo com as condições e os meios de produção permanecem, no conjunto, idênticos; por este fato, o mundo é refletido da mesma maneira sob a forma das mesmas significações, tanto na consciência individual como no sistema da significações linguísticas que formam a consciência da coletividade. [...] Do ponto de vista do desenvolvimento da consciência, é o alargamento do domínio do consciente, ao qual conduz necessariamente o desenvolvimento do trabalho, dos instrumentos, das formas e relações de trabalho que prepara a separação do sentido e da significação. A primeira transformação importante, no sentido do alargamento do domínio do consciente, é realizada pela complexidade das operações de trabalho e dos instrumentos. A produção exige cada vez mais, de cada trabalhador, um sistema de ações subordinadas umas às outras e, por consequência, um sistema de fins conscientes que por outro lado, entram num processo único, numa ação complexa única. Psicologicamente, a fusão de diferentes ações parciais numa ação única constitui a sua transformação em operações. Por este fato, o conteúdo que outrora ocupava, na estrutura, o lugar de fins (itálico do original) conscientes de ações parciais, ocupa doravante, na estrutura da ação complexa, lugar de condições de realização da ação. Isto significa que doravante as operações e condições de ação também elas podem entrar no domínio do consciente. Em contrapartida, não entram aí da mesma maneira que as ações e seus fins. [...] A ação e o seu fim, quando entram na composição de outra ação, não se "apresentam" (aspas do original) diretamente na consciência. Isto não significa que deixem de ser conscientes. Ocupam apenas outro lugar na consciência; são igualmente, por assim dizer, controlados, conscientemente, o que significa que, em certas condições, podem ser conscientes.

A língua, verdadeiramente, não se funda apartada dos eventos humanos e, portanto, é impossível o ato de fazer a linguagem nas interlocuções entre as pessoas radicada apenas na razão ou formalização, o jogo discursivo é também movido pela emoção, dependendo dos valores, saberes e crenças que os sujeitos carregam consigo em razão, sobretudo, da sua história. Consequentemente, o movimento das relações sociais nem sempre se dá pela via da aceitação; ao contrário, inclusão e exclusão soerguem a produção do sujeito humano: fazendo ascender tensões entre as diferenças de lugares, desejos, necessidades, interesses, motivos e objetivos. As emoções e seus modos de expressão ratificam a impossibilidade de ações unas, atestando 
que o sujeito percorre trilhas específicas para produzir suas compreensões, tendo em vista que mobiliza saberes vindos tanto do plano racional como do sensível.

Por conseguinte, o discurso de emoção não só é imprescritível, nunca pode ser igual pela repetição, mas também como é um ato praticado por um sujeito situado e encarnado, tendo em vista que, na atividade do trabalho docente, as relações são relativamente "[...] refletidas nas significações particulares, e por um lado, este conteúdo é refletido não nas próprias significações. [...] devemos igualmente ter presentes no espírito as transformações que as formas da linguagem e as formas da consciência social sofrem.” (LEONTIEV, 2004, p. 137).

No que tange às transformações da linguagem e da consciência social, faz-se mister destacar que, na perspectiva de Leontiev (2004, p. 128), “[...] as relações entre os homens transformaram-se cada vez mais em puras relações entre as coisas ${ }^{9}$ que se separam ("se alienam") do próprio homem. O resultado é que a sua própria atividade deixa de ser para o homem o que ela é verdadeiramente.” Na investigação psicológica calcada na Teoria HistóricoCultural, na Teoria da Atividade e na perspectiva Desenvolvimental, essas particularidades de estrutura da consciência humana exigem a sua consideração, sob pena de que seja suprimido o concreto histórico, focalizando de modo abstrato o homem em geral, posto que, segundo Leontiev (2004, p. 133), “[...] alienação não significa muito simplesmente que qualquer coisa deixou de existir para mim. O trabalho alienado não é de modo algum um trabalho inexistente para o operário. Existe para ele, por certo, e entra aliás duplamente na sua vida: de maneira negativa e de maneira positiva.".

Reafirma-se, assim, a natureza contraditória da atividade por meio do conteúdo da própria vida humana; relacionando-a à estreiteza da consciência social e consciência de classe, pois sua consciência individual é engendrada nas condições de uma consciência social, à medida que se apropria da realidade pelo prisma dos conhecimentos, das significações e das representações urdidas socialmente, qual seja:

[...] a ideologia dominante, na sociedade de classes, é a da classe dominante que reflete e reforça as relações sociais existentes. [...] essas relações escravizam o homem, submetem a sua vida e nela criam contradições internas. Tal como a vida humana não se encarna totalmente nestas relações, assim os sentidos engendrados pela atividade humana não se encarnam totalmente nestas relações nem de maneira autêntica nas significações que refletem estas relações estranhas à vida. É esta a causa da imperfeição e da inadequação da consciência e da conscientização. Devemos sublinhar que, se bem que se trate

\footnotetext{
${ }^{9}$ Acerca disso, convém o registro (mas essas relações não se reduzem apenas a essa situação) sobre o que se convencionou chamar na contemporaneidade de "Internet of Things (IoT), modo como os objetos físicos estão conectados e se comunicando entre si e com o usuário, através de sensores inteligentes e softwares que transmitem dados para uma rede, como se fosse um grande sistema nervoso que possibilita a troca de informações entre dois ou mais pontos." Disponível em: https://www.proof.com.br/blog/internet-das-coisas/ Acesso em: 28/03/2020.
} 
de uma inadequação da consciência interna, ela não pode ser eliminada de outro modo a não ser pela transformação prática das condições objetivas que a criaram. Mais precisamente se essas condições se conservam, esta inadequação só pode ser eliminada à custa de um repúdio pela consciência da vida real ou num processo de luta ativa contra as ditas condições. O homem esforça-se por pôr um fim à desintegração da sua consciência. Mas se busca a adequação e a autenticidade da sua consciência, não é por amor abstrato à verdade. Isso apenas traduz a sua aspiração a uma verdadeira vida; é por tal razão que esta aspiração é tão intensa e os processos da tomada de consciência - os mais secretos, da "vida interior" do homem - tomam por vezes um curso realmente dramático (LEONTIEV, 2004, p. 139).

Desse modo, a apropriação leva o sujeito à reprodução, na sua atividade objetal externa, do potencial adquirido historicamente por meio da sua participação no coletivo e subsequente processo de interiorização, entendendo que:

[...] apropriar-se não tem o sentido de "guardar" um conhecimento novo por meio do uso da memória para reproduzi-lo depois [...]. Tem o sentido de confrontá-los com conhecimentos anteriores, caracterizá-los, analisá-los e experimentar suas possibilidades no momento em que são mais necessários: no momento de objetivação [...]. A partir daí manter, permanentemente, o fluxo entre pensar o que foi feito, avaliar, recorrer novamente às características do conceito, num esforço de reorganização das generalizações, ou seja, das deduções do sujeito a partir das propriedades do conceito [...], produzidas para reconstruir as práticas, de modo contínuo, contribuindo, dessa forma, para o desenvolvimento [...]. A "apropriação" envolve as dimensões teoria e prática, que [...] se refere a conhecimentos do campo da teoria histórico-cultural necessários à docência. Estas duas dimensões têm naturezas distintas, embora contraditoriamente só se efetivem em unidade dialética. A instrumentalização/formação só pode se efetivar neste movimento. Uma proposta de formação que pretenda colaborar com o desenvolvimento do formador de professores não pode prescindir das duas dimensões: teoria e prática, tampouco fragmentá-las em momentos não complementares, como se não formassem o todo contraditório da docência. Da mesma forma, a tecitura das proposições didáticas demanda o envolvimento direto dos professores, com indicações referentes aos nexos conceituais, ou seja, ao que estrutura e fundamenta um conceito, considerados na produção de tais propostas (SOUSA, 2016, p. 151).

Essa compreensão sobre apropriação é que mobiliza e concede movimento à complexa estrutura do trabalho docente enquanto atividade humana e inclui componentes como: necessidades, motivos, objetivos, tarefas, ações e operações, em contínuo fluxo de interdependência e transformação. As perejivaniia docentes na sociedade e/ou no coletivo profissional, essência do ser humano, permitem que o professor na utilização de instrumentos que representam o ideal, avaliando e discutindo sua própria atividade a partir das perspectivas de outros membros do coletivo, faça com que a atividade individual tenha a possibilidade de tornar-se uma representação ideal, impactando assim no desenvolvimento da consciência pela 
ótica da relação de indissociabilidade da unidade entre o ideal e o real, tendo a atividade relevância preeminente no processo. A gênese da atividade objetal-prática circunstancia-se à natureza e ao sujeito coletivo, pois situa-se aí a diversidade de atividades e o ponto de estruturação consciente da sua atividade individual, tendo em vista que:

\begin{abstract}
A base de todo conhecimento humano é a atividade objetal-prática, produtiva: o trabalho [...]. A transformação do que dá a natureza é um ato de superação de sua imediatez. Por si mesmos os objetos naturais não adquiririam a forma que se lhes dá conforme as necessidades do homem social. Além disso, as pessoas devem ter em conta, por antecipação, as propriedades dos objetos que permitem produzir as metamorfoses correspondentes tanto à finalidade formulada como à natureza dos objetos mesmos. Em consequência, no processo de trabalho o homem deve tomar consideração não só as propriedades externas dos objetos, mas também as conexões internas que permitem mudar suas propriedades e fazê-los passar de um estado a outro. Não se pode por em evidência estas relações enquanto não se realize a transformação prática dos objetos nem sem ela, já que só neste processo ditas relações se põem em evidência (DAVYDOV, 1988, p. 118).
\end{abstract}

Consequentemente, após as transformações do que a natureza nos oferece, uma vez criados os objetos, estes entram em relação com outros objetos no meio social, através das atividades humanas, concebendo o movimento que provoca a superação da imediatez do objeto em função da condição de mediatização que coloca em evidência, nesse movimento, suas conexões internas, essenciais, posto que o "objeto obtém esta imediatez em relação consigo mesmo, mas só por meio de determinados procedimentos da atividade do homem e da forma de movimento do objeto se reproduz nesta atividade." (DAVYDOV, 1988, p. 119). Sendo assim, a atividade está internamente conectada ao conceito de ideal, ou seja, ao devir do objeto, factível pela atividade consciente do sujeito em função de necessidades finalidades, imagens que o influem, conforme os significados linguísticos e simbologias, até alcançar o resultado objetal correspondente a uma necessidade, o que é executados por meio de ações e operações.

No âmago desse processo está a ontogênese e a apropriação da cultura, densamente relacionadas ao campo do ideal e do desenvolvimento da consciência, que direcionam as capacidades imprescindíveis para que os sujeitos criem e/ou reproduzam utensílios, ferramentas e objetos, capacidades essas que são possibilitadas por meio da historicidade que evidencia os procedimentos necessários a tais produções, como também as contradições postas por cada realidade objetiva particular. A ontogênese, ao demonstrar o desenvolvimento histórico e cultural do ser, revela como fundante o papel da imaginação para o desenvolvimento humano e de suas atividades. A Atividade relaciona-se a uma estrutura e esquemas universais, na 
transformação de si e do mundo natural pelo próprio homem, quer dizer, mostra-se na Atividade a natureza universal do sujeito humano pela lógica dialética.

Ao se discutir o trabalho docente e o seu processo formativo, compreendeu-se que a apropriação pela aprendizagem transcorre ao longo de toda a história social, impactada pelo mundo circundante, por meio da sua atividade produtiva, em seu significado social. A maneira como os docentes se organizam no trabalho, como se relacionam entre si, bem como nas diversas atividades sociais e na vida privada, configurada pelas diferentes estruturas econômicas e culturais, impacta na constituição do processo de aprendizagem. A educação se faz presente em todos os campos do cotidiano, de modo planejada ou não, mas o objetivo aqui foi discutir mais detidamente a Atividade Pedagógica, enquanto obutchénie desenvolvedora, condição indispensável à humanização e formação docente.

O exercício da docência, enquanto atividade humana, pauta-se na coletividade, constituindo-se por meios das perejivaniia, em contínuo processo de vospitanie e de obutchénie. Desse modo, as necessidades formativas e a própria formação foram arroladas como nucleares para a vida cotidiana, portanto, indeléveis para o trabalho docente e o seu processo formativo, nas suas implicações objetivas e subjetivas, nos seus modos de ser-pensaragir. Para compreender a categoria trabalho como unidade dialética, foi necessário captar nas relações de trabalho o nuclear em movimento histórico que evidenciou o essencial por meio da totalidade, da consciência e da atividade, qual seja, o processo de formação docente.

Como resultado, apresenta-se, a seguir, do Isolado intitulado "A Aprendizagem Docente", o Episódio intitulado "Afecções, afetos e emoções - sentimentos delineadores da Atividade Pedagógica".

\section{AFECÇÕES, AFETOS, EMOÇÕES E SENTIMENTOS DELINEADORES DAS PEREJIVANIIA NO MOVIMENTO DA ATIVIDADE PEDAGÓGICA}

Solidão? Solitude? Coragem? Desejo? Medo? Prazer? Imobilidade? Nesse episódio foram reveladas as afecções, os afetos e as emoções sob as quais se compuseram os sentimentos dos docentes partícipes dessa Atividade Pedagógica, no que tange à aprendizagem de sertornar-se-sentir-se professor, ao se considerar a capacidade humana de elevar os instintos à altura da consciência, por meio dos significados e mediação das afecções pelos signos sociais, aumentando ou diminuindo a potência de ação. Assim, a partir do Materialismo Histórico Dialético, da Teoria Histórico-Cultural da Atividade e da Didática Desenvolvimental, analisouse a organização e o desenvolvimento das ações de formação contínua, em mobilização pela 
prospecção liberdade-felicidade, instigada pelas unidades afeto-cognição, rupturadesenvolvimento, motivo-objeto, imaginação-criação e conteúdo-forma, enquanto processo de desenvolvimento ontogênico e devir histórico.

Segue a cena A1.1, ocorrida na reunião com os partícipes, em 06/06/2017.

Cena A1.1: Reunião com Partícipes - 06/06/2017

\section{$\mathbf{N}^{\circ} \quad$ PARTÍCIPE}

$1 \quad$ Liberdade

Lispector

2
Felicidade

Suassuna

Liberdade Lispector

Felicidade Suassuna

Liberdade Lispector

Felicidade Suassuna
Então assim ainda tem muito isso o pensamento do pedagogo é um pensamento, o pensamento do enfermeiro é um pensamento, do administrador é outro pensamento. Às vezes é o conceito de cada um que não dialoga.

E cada pessoa tem a sua própria história de vida e, consequentemente, tem a formação que a sua área lhe permite. $\mathrm{O}$ acesso a determinado tipo de conhecimento que é possibilitado por certas áreas.

Eu fiz uma pós-graduação em docência pra poder me sentir confortável pra dar aula.

Aí novamente: onde é que a gente aprende a ser professor? A formação inicial não é suficiente para isso, pela imitação $[. .$.

Às vezes eu me pego fazendo coisas que ele fazia, entendeu? Às vezes eu falo: "poxa, tá parecido com meu professor."

Não tem como a gente não aprender no dia-a-dia, por isso que eu entendo como primordial a formação continuada. No dia a dia, se você estiver com o outro você não vai ser obrigada a aprender solitariamente. A gente aprende muito com o outro e pelo outro. [...] um projeto que é criado numa instância superior vem verticalizado e o que acontece é que às vezes é antagônico com a necessidade formativa do professor. Aliás, é um dos motivos que muito fortemente me faz pensar que a validade disso é enorme e que a gente precisa disso especialmente para conhecer a si próprio enquanto instituição [...] Mas, na realidade, essa construção do conhecimento não para porque ela se dá no próprio exercício da profissão e acompanha a gente pela vida toda. Aí a gente é professor e a gente é professor de determinada área e tem propriedade dos conhecimentos de determinada área. Só que não basta o conhecimento relacionado a uma área específica porque a gente lida com pessoas.

Eu acho que é mais pra aquela pessoa que dá aquele curso lá se manifestar de alguma forma e a gente não tem proveito nenhum.

Porque quando vem a verticalização, ela já vem com uma intencionalidade, entende?! Que muitas vezes direciona para um mundo contrário do que a gente entende que seja fator para a expansão da nossa consciência [...] Quantas questões a gente constrói e tem necessidade das respostas, que não são respostas definitivas, mas que a gente vai precisando dessas respostas também para ter estabilidade nas atitudes de pesquisa, compreendendo de forma mais ampla os conhecimentos. A gente vai formando para agir conscientemente com base neles e não a partir do vazio, né? Do nada... porque esse é um processo extremamente solitário, tem sido solitário. Por isso que defendo a importância disso... da necessidade da gente porque quando isso acontece a gente vai e participa não por imposição, a gente vai porque aquilo é significativo para a gente...é aquilo que eu preciso aprender a fazer no cotidiano, que eu não me sinto capaz, geralmente o professor verbaliza muito sobre imediatismo e quer uma resposta imediata, isso já indica uma concepção de formação continuada. Tem coisas que a minha formação não me permite ver que eu posso ver pelo seu sentido... 
Inicialmente, no "Episódio A1: Afecções, afetos e emoções - sentimentos delineadores do movimento da Atividade Pedagógica", na Cena A1.1, Liberdade Lispector (trecho 1) manifesta a sua contestação sobre o não-diálogo entre os conceitos das diversas áreas de conhecimentos, relacionadas às licenciaturas e bacharelados ofertados no CAFS: na sua compreensão, os conceitos que corroboram com a constituição da identidade do profissional de cada curso não os aparta entre si, ao contrário, podem, sim, dialogar, o que sinaliza a sua capacidade de compreender a universalidade do conhecimento científico e sua relação com a obutchénie, evidenciando o seu entendimento sobre os nexos existentes entre as dimensões universal, particular e singular dos fenômenos históricos. Felicidade Suassuna (trecho 2) destacou a historicidade do processo de formação de cada sujeito, pontuando sobre o acesso a cada conhecimento em sua respectiva singularidade. No trecho 3, Liberdade Lispector afirma que cursou uma pós-graduação em docência para se sentir mais “confortável” como professor (sua formação inicial é bacharelado), ao que Felicidade Suassuna (trecho 4) retruca assinalando sobre a "insuficiência" da formação inicial e, retoricamente, cita a "imitação" como recurso de aprendizagem para o professor. Liberdade Lispector (trecho 5) manifesta anuência ao dizer que às vezes se pega "fazendo coisas" semelhantes ao que o seu professor fazia.

Compreende-se que, nos trechos supracitados da Cena A1.1, as unidades conteúdoforma, imaginação-criação e afeto-cognição manifestaram-se na capacidade de entendimento sobre as relações entre o modo de ensinar-aprender-ensinar, a apropriação do conhecimento e do seu próprio conteúdo em si, expressos em dialeticidade, pois realçou-se que é necessária a apreensão das relações internas do fenômeno histórico, tendo em vista que estas não se revelam na aparência de tais fenômenos, posto que é exigida acurada análise, a fim de que seja possível captar tais relações. Desse modo, conforme evidenciou Liberdade Lispector (trecho 1) ao se reportar à relação entre conceitos, interpreta-se que importa tanto o conteúdo quanto a maneira como se organiza este conteúdo, ou seja, a forma, a fim de que ocorra a mediação externa por meio dos signos, provocando as alterações internas por meio dos significados sociais em interligação com os sentidos pessoais. No trecho 2, Felicidade Suassuna apontou para a produção de conhecimento oportunizada a partir do conteúdo das diversas áreas de conhecimento, evidenciado novamente a unidade conteúdo-forma, posto que as diferentes formas de organização curricular e instrumentalização destas possibilitam diferentes aprendizagens. Felicidade Suassuna, no trecho 6, referindo-se à formação contínua, destacou que a verticalização do ensino, em função dos conteúdos e do formato de execução, não produz conhecimentos pautados nas necessidades formativas dos professores, evidenciando mais uma vez a unidade conteúdo-forma. Ainda no trecho 6, Felicidade Suassuna asseverou sobre não 
bastar os conhecimentos em seus aspectos conceituais, pois ao lidar com pessoas, também se lida com as emoções, o que colocou em destaque a compreensão sobre a unidade afetocognição, ou seja, ao se elaborar o pensamento teórico estão postos nesse processo a afetividade e a volição no campo da consciência. Felicidade Suassuna, no trecho 8, ao destacar que vislumbra outras perspectivas pelo sentido do outro, sinalizou para a gênese que dispara a imaginação-criação, pois a abstração colabora com a efetivação do processo criativo e expansão da consciência.

Assim, no processo pedagógico-psicológico de produção do conhecimento, a capacidade de análise decorre da compreensão da sociedade enquanto sistema que serve a determinados interesses de produção na relação com a natureza e com o trabalho humano, tendo por consequência a compartimentalização dos conhecimentos, que é decorrente de tal modelo de sociedade compreendida equivocadamente como forma unívoca de organização social. Portanto, a compreensão manifestada por Liberdade Lispector (trecho 1) evidencia expansão de consciência que capta tal essência podendo, por analogia, aplicar esse entendimento na compreensão da mente como um todo, no funcionamento sistêmico entre suas partes.

A Atividade Pedagógica, enquanto movimento coletivo dialético, faz abrolhar as condições materiais para que, a partir da história de cada sujeito sócio-pessoal, sejam produzidos os significados sociais e os sentidos pessoais que impactam na constituição da afetividade humana, plasmada pelas afecções, afetos, emoções e sentimentos docentes, abarcando as ideias, os signos e as essências, evocadas pela interconexão das funções psicológicas superiores, no movimento de ascensão do abstrato ao concreto no lógico-histórico dos conceitos. Sendo assim,

Quando percebemos, percebemos ao mesmo tempo nossas afecções corporais e nossas ideias dessas afecções, de modo que as coisas são experimentadas pela mente e pelo corpo não como unidades individualizadas, mas como um complexo múltiplo. Do mesmo modo, as atividades do conhecimento não ocorrem uma de cada vez ou uma depois da outra de modo sucessivo, mas se dão simultaneamente. Assim, as mentes são, portanto, mais ou menos aptas a perceber e compreender essa pluralidade simultânea que é constituinte da realidade e de sua própria natureza. A simultaneidade, entretanto, é uma relação temporal, e por isso deve ser entendida em conjunção com outras relações lógicas e mereológicas, como, por exemplo, a continuidade (ou descontinuidade), a diferença e a proporcionalidade. (PUGLIESE, 2017, p. 122).

Ou seja, de tudo o que na humanidade está impresso histórica e culturalmente, o movimento e a contradição são inexoráveis. A vida docente traz essa indelével marca: sertornar-se professor no ambiente acadêmico, tendo em vista a produção de consensos, quando 
assim for possível, exige posicionar-se na perspectiva da diversidade de compreensões acerca da sociedade, da humanidade e de suas relações. Qual a relação entre a solidão e o fato de posicionar-se a partir dessa perspectiva? Esmagadora e desmobilizadora, quando o caminho trilhado for o da individualidade. Libertadora, quando viabilizada pela atividade coletiva, entendendo liberdade como consciência das necessidades que, em Atividade Pedagógica, transformam-se em motivos formadores de sentido, funcionando não apenas como motivosestímulos.

No trecho 6, Felicidade Suassuna discorre sobre a tal solidão. Não sobre solicitude, movimento intencional necessário para o processo criativo. Refere-se à solidão pedagógica que, na sua compreensão, antagoniza-se ao processo de formação contínua, destacando que tal processo, quando verticalizado, vai de encontro à necessidade formativa do professor. Ao dimensionar o sujeito contemporâneo, entende-se que o capitalismo em toda a sua extensão e em articulação com o seu modo de produção, provoca impacto na vida docente ao transferir a compartimentalização para o ensino e individualizar o trabalho docente, acoplando à solidão ao sentimento de insatisfação humano, em função da sensação de não pertencimento, de não identificação com o outro, fruto da diferença. Qual o lugar do sujeito sócio-pessoal nesse processo? Os motivos individuais que fazem eclodir a necessidade de estar em coletivo são diversos e estão sujeitas a regulações sociais que afetam tais desejos.

Felicidade Suassuna segue afirmando, no trecho 6, que o processo de formação contínua, desencadeado pelo-outro-com-o-outro, gera o autoconhecimento, o que culmina no conhecimento da própria Instituição de Ensino Superior (IES), nesse caso, a UFPI-CAFS em seu contexto histórico, cultural e social, acompanhando o docente pela vida de modo permanente. Novamente eclode a unidade conteúdo-forma na cena A1.1, quando Felicidade Suassuna assinala para a universalidade dos conhecimentos científicos, ao apontar a necessidade de conhecimento que abarque a formação da personalidade humana como um todo de modo sistêmico. A insatisfação com a verticalização da formação docente é explicitada por Liberdade Lispector no trecho 7, ao fazer referência ao "Curso de Iniciação à Docência do Ensino Superior", ofertado pela UFPI, por força de obrigatoriedade estabelecida em cada edital de concurso. Os editais preveem que tal curso seja oferecido antes de os recém-concursados adentrarem à sala de aula, mas às vezes, transcorre um ano para que ocorra o curso. A carga horária é de apenas oito horas.

No trecho 8, Felicidade Suassuna reitera sobre a verticalização, destacando sobre as possíveis intencionalidades que, no seu entendimento, podem configurar antagonização às concepções de mundo que os docentes entendem ser adequadas à expansão da consciência 
humana. Interpreta-se nesse mesmo trecho que Felicidade Suassuna, ao mencionar a provisoriedade da ciência no que se refere à transitoriedade dos conhecimentos científicos, devido ao movimento histórico de avanço ou até mesmo de possíveis retroações que lhe são peculiares devido à natureza da ciência em si, compreende a inerente contradição posta pela unidade dialética enquanto categoria. Outrossim, questiona o imediatismo, evidenciando que assim o entende como prejudicial tanto ao processo de Vospitanie como de Obutchénie, conforme interpretou-se, pois:

\begin{abstract}
A contradição é [...] real, está nas coisas mesmas. Ela não é uma transposição conceitual do movimento, nem tão somente uma expressão limitada e provisória das coisas, resultado de uma análise incompleta e fragmentária. A essência das relações reais é, sendo relação, ser luta e choque. Termos e relações são tomados não como eternos, mas como móveis. Estas fórmulas não constituem uma apologia da contradição, do dilaceramento ou do absurdo. (LÊNIN, 2011, p. 25).
\end{abstract}

Longe disso, a contradição funciona como o motor da atividade humana, e assim também o é na Atividade Pedagógica. A colaboração entre docentes com base nas ações de linguagem, que não excluem os confrontos, cria os conflitos necessários para se chegar a uma síntese, necessária na produção do conhecimento. Assim, nas interações do coletivo docente, criam-se os vínculos intelectuais necessários à aprendizagem ético-afetiva, por meio da relação tese-antítese-síntese. No movimento histórico e contraditório das afecções, afetos e emoções, desenvolver o sentimento de pertença, ser afetado pela sensação de que a sua compreensão sobre o real não é isolada, provém a conexão entre os membros do coletivo e destes com a realidade, expandindo a potência de ação, impactada pelo lastro da alteridade humana. Estar em contato com o outro, considerando as suas diferenças, valida a sensação identitária docente.

Adiante, apontam-se resultados da pesquisa, sinalizando sobre o cenário posto à vida docente universitária.

\title{
4 À ESPERA DE OUTRAS CONVERSAS...
}

Confuso, arriscado, doloroso: é assim o cenário posto, o tempo de apologia à ignorância em todos os sentidos, quer seja de depauperação da potência do intelecto por meio de mecanismos de controle e perseguição política, quer seja por imposições e cortes que dificultam o funcionamento da universidade pública brasileira, provocando, desse modo, a dominação estrutural e a subordinação hierárquica por meio da imposição. Indesejado, porém não surpreendente, porque é um projeto que se planeja a longo tempo histórico: o projeto Neoliberal. 
O que aparentemente ocorreu de maneira abrupta, repentina e de modo incompatível, na sua essência, é resultado de planejamento político traçado com vistas a robustecer o Capitalismo. Educar/dormir/deseducar: foi essa a tríade em forma de afecção que se lançou sobre a educação e o trabalho docente. A mercantilização do ensino opera de modo a transformar a educação em mercadoria, gerando e transmitindo valores que corroboram com os interesses dominantes o que inviabiliza o seu caráter emancipatório. Entretanto, a educação é elemento constitutivo imprescindível à conjuntura que se proponha a romper com a estrutura consolidada da ordem capitalista, indo de encontro à conformidade instituída, à alienação e ao fanatismo que empobrecem a humanidade. Errática ao sistema vigente, a educação pautada na transformação-emancipação provoca a expansão da consciência crítica, conectando-a dialeticamente à realidade social.

Enquanto devir histórico, no contexto em que se produziu essa pesquisa, a aprendizagem docente afilia a formação contínua como intrínseca à potencialização da obutchénie desenvolvimental pautada no trabalho coletivo e interdisciplinar, na unidade teoria-prática, na expansão da consciência humana, em pujante formação teórica, no aprendizado ético-afetivo, no comprometimento social e político dos docentes com as transformações sociais necessárias e na constituição da identidade profissional dos docentes. Isso tudo reverberou nas afecções, nos afetos, nas emoções e nos sentimentos que delinearam o movimento da Atividade Pedagógica e na vida docente na interconexão entre o método, a metodologia, no engajamento político, didático e científico, posto que não há neutralidade em nenhum ato humano. A docência não se constitui apartada da politicidade, portanto, também o método e a metodologia de trabalho também não.

\section{REFERÊNCIAS}

ALVARADO-PRADA, Luís Eduardo. Pesquisa Coletiva na Formação de Professores. Revista de Educação Pública. Cuiabá, v. 15 n. 28 maio./ ago. 2006.

ALVARADO-PRADA, Luís Eduardo; OLIVEIRA, Valéria de Freitas. Concepções e políticas de formação continuada de professores: sua construção. Ensino Em-Revista, Uberlândia, v.17, n.1, p. 111-133, jan./jun. 2010.

ALVARADO-PRADA; Luís Eduardo; LONGAREZI, Andréa Maturano. Aprendizagem docente na formação continuada de professores em serviço. In: GALVÃO, Afonso; SANTOS, Gilberto Lacerda dos. (Org.). História e pensamento educacional, formação de educadores, políticas públicas e gestão da educação. Brasília: Líber Livro Editora: ANPEd, 2008, v. 1, p. 105-122. 
BADIOU, Alain. A filosofia deve enfrentar o amor e a felicidade. Disponível em: https://lavrapalavra.com/2015/08/07/a-filosofia-deve-enfrentar-o-amor-e-a-felicidade/. Acesso em: 26 set. 2019.

CARAÇA, Bento de Jesus. Conceitos Fundamentais da Matemática. Gradiva Edições, Portugal, 1951.

DAVYDOV, Vasily Vasilyevich. Problemas do ensino desenvolvimental: a experiência da pesquisa teórica e experimental na psicologia. Trad. de José Carlos Libâneo. Educação Soviética, $\mathrm{n}^{\circ} 8$, agosto, 1988.

DIAS DE SOUSA, Walêska Dayse. Processos de imitação-criação como constituidores da práxis pedagógica. 2016. 343 fl. Tese (Doutorado em Educação) - Universidade Federal de Uberlândia, Uberlândia/MG, 2016.

FEROLA, Bianca de Carvalho. Contribuições para a Didática Desenvolvimental no Ensino Médio: ações didáticas para a formação de conceitos científicos em Biologia. Monografia (Graduação em Ciências Biológicas) - Universidade Federal de Uberlândia, 2016.

FEROLA, Bianca de Carvalho. O desenvolvimento integral na obra de Leonid Vladimirovich Zankov (1957-1977): um olhar para os princípios e orientações metodológicas. 2019. 78fls. Dissertação (Mestrado em Educação) - Universidade Federal de Uberlândia, Uberlândia, MG, 2019.

FERREIRA, Ione Maria. Formação de professores e desenvolvimento da personalidade na Educação Infantil. Relatório de qualificação (Doutorado em Educação) - Universidade Federal de Uberlândia, Uberlândia/MG, 2019.

FRANCO, Patrícia Lopes Jorge. O desenvolvimento de motivos formadores de sentido no contexto das atividades de ensino e estudo na escola pública brasileira. 2015. 359fl. Tese (Doutorado em Educação) - Universidade Federal de Uberlândia, Uberlândia, MG, 2015.

FRIGOTTO, Gaudêncio. Escola e trabalho numa perspectiva histórica: contradições e controvérsias. Conferência proferida na Faculdade de Psicologia e de Ciências da Educação da Universidade de Lisboa, XVII Colóquio Afirse - secção portuguesa, "A escola e o mundo do trabalho", a 12 de fevereiro de 2009. Sísifo - Revista de Ciências da Educação, n.9, mai/ago 2009, p. 129-136. Disponível em:

http://www.afirse.com/archives/cd2/confer\%C3\%AAncias/Gaudencio\%20Frigotto.pdf Acesso em 13 nov. 2017.

JESÚS, Sônia Ferreira de. Formação continuada da gestão pedagógica: uma análise na perspectiva da teoria da personalidade e obutchénie por unidades. 2021. 180 fl. Relatório de qualificação de Tese (Doutorado em Educação) -Universidade Federal de Uberlândia, Uberlândia/MG, 2021.

LÊNIN, Vladimir Ilyich Ulianov. Cadernos sobre a dialética de Hegel. Tradução de José Paulo Netto. Pensamento Crítico, 16. Rio de Janeiro: Editora UFRJ, 2011.

LEONTIEV, Alexis. O desenvolvimento do psiquismo. 2. ed. São Paulo: Centauro, 2004.

LONGAREZI, Andrea Maturano; DIAS DE SOUSA, Walêska Dayse. Unidades possíveis para uma obutchénie dialética e desenvolvedora. Linhas Críticas (UNB), v.24, p. 278-299, 2018. https://doi.org/10.26512/lc.v24i0.19815 
LONGAREZI, Andrea Maturano; SILVA, Jorge Luiz da. Pesquisa-formação: um olhar para a sua constituição conceitual e política. Revista Contrapontos - Eletrônica, v. 13, n. 3, p. 214225, set./dez. 2013. https://doi.org/10.14210/contrapontos.v13n3.p214-225

MARRA, José Bartolomeu Jocene. Formação de formadores de professores para e por um Ensino Desenvolvimental de línguas: uma intervenção didático-formativa na educação superior em Moçambique. 2018. 147fl. Tese (Doutorado em Educação) - Universidade Federal de Uberlândia, Uberlândia/MG, 2018.

MOURA, Manoel Oriosvaldo de. O educador matemático na coletividade de formação: uma experiência com a escola pública. 136 fl.Tese (Livre Docência em Metodologia do Ensino de Matemática) - Faculdade de Educação. Universidade de São Paulo - USP, São Paulo, 2000.

PUGLIESE, Nastassja. Os três gêneros de conhecimento e a natureza de suas relações. Spinoza e nós, v. 2: Spinoza atual/inatual. Rio de Janeiro: Ed. PUC-Rio, 2017.

SAWAIA, Bader Burihan. Cultura: A dimensão psicológica e a mudança histórica e cultural. A emoção como locus de produção do conhecimento: uma reflexão inspirada em Vygotsky e no seu diálogo com Espinosa. III Conferência de Pesquisa Sócio-Cultural, Campinas, SP, 2000 .

SAWAIA, Bader Burihan. Fome de felicidade e liberdade. In: Muitos Lugares para Aprender. Centro de Estudos e Pesquisas em Educação, Cultura e Ação Comunitária - CENPEC - São Paulo; CENPEC/Fundação Itaú Social/Unicef, 2003.

SOUZA, Leandro Montandon de Araújo. A sociologia no ensino médio: princípios e ações didáticas orientadoras de um ensino que possibilite o desenvolvimento de adolescentes em uma perspectiva histórico-cultural. 2016. 209fl. Dissertação (Mestrado em Educação) Universidade Federal de Uberlândia, Uberlândia/MG, 2016.

SOUZA, Leandro Montandon de Araújo. A unidade Personalidade-Psique-Atividade no pensamento de Sergei L. Rubinstein: contribuições para o campo educacional. 2019. 308fl. Tese (Doutorado em Educação) - Universidade Federal de Uberlândia, Uberlândia/MG, 2019.

SPINOZA, Baruch de. E do caminho pelo qual melhor se dirige ao verdadeiro conhecimento das coisas. In: Tratado da Correção do Intelecto. Acrópolis Filosofia, 1662. p. 1-30. Disponível em: http://www.dominiopublico.gov.br/download/texto/cv000066.pdf. Acesso em: 28 mar. 2018.

VIGOTSKI, Lev Semenovitch. Psicologia da Arte. São Paulo: Martins Fontes, 1999.

VIGOTSKI, Lev Semenovitch. Sete aulas de L.S. Vigotski sobre os fundamentos da pedologia. Rio de Janeiro: EPapers, 2018.

VYGOTSKY, Lev Semenovitch. Teoria e Método em Psicologia. 3. ed. São Paulo: Martins Fontes, 2004.

\section{SOBRE AS AUTORAS}

Grasiela Maria de Sousa Coelho é Doutora em Educação pela Universidade Federal de Uberlândia (UFU), Mestre pela Universidade Federal do Piauí. Graduada em Licenciatura Plena em Pedagogia pela 
Universidade Federal do Piauí. Atualmente é professora da Universidade Federal do Piauí no Campus Amílcar Ferreira Sobral em Floriano, no Curso de Licenciatura em Pedagogia, na área de Linguagem e Educação.

E-mail: grasi2909@gmail.com

ORCID: https://orcid.org/0000-0001-8465-4316

Andréa Maturano Longarezi Pós-doutora em Educação, pela Faculdade de Educação da Universidade de São Paulo, sob a supervisão do Prof. Dr. Manoel Oriosvaldo de Moura (2018). Doutora em Educação Escolar pela Universidade Estadual Paulista 'Júlio de Mesquita Filho' (2001); mestre em Educação - Metodologia do Ensino- pela Universidade Federal de São Carlos (1996) e graduada em Ciências Sociais (Licenciatura Plena e Bacharelado) pela Universidade Estadual Paulista Júlio de Mesquita Filho (1992). Atualmente é professora associada na Faculdade de Educação, da Universidade Federal de Uberlândia, atuando como membro do corpo permanente nos cursos de Mestrado e Doutorado do Programa de Pós-graduação em Educação dessa instituição; é coordenadora substituta do Programa de Pós-graduação em Educação da Faculdade de Educação da UFU;

E-mail: andrea.longarezi@gmail.com

ORCID: https://orcid.org/0000-0002-5651-9333 